\title{
TURKS IN THE OTTOMAN IMPERIAL PALACE*
}

\author{
İ. Metin Kunt
}

Sans family, sans ethnicity?

To a non-specialist "Turks in the Ottoman Imperial Palace" may sound reasonable, even expected, certainly innocuous, but in Ottoman studies the expression comes with a question mark and an exclamation point. Both in terms of the underlying principles and in terms of actual practice there were supposed to be no Turks in the Ottoman palace, except in special circumstances. But from the late sixteenth century, as critics put it, Turks and Kurds and other riffraff penetrated the palace and so caused the deterioration of the venerable institution of the imperial household. ${ }^{1}$

Any royal palace might be cosmopolitan to a certain degree but in Europe, except perhaps in the multi-ethnic Habsburg capitals, Madrid and Vienna, the main national element in a given polity would constitute the largest ethnic component in the royal establishment. In Islamic polities the reverse was true. Caliphs and sultans preferred to distance themselves from the main ethnic groups in society by developing household troops composed of outsiders. Furthermore, these outsiders were imported as enslaved, deracinated warriors owing sole loyalty to their masters: the perfect troops for dynastic empires. Slavs, Turks, Franks, pagan or Christian but always non-Muslim for they were slaves, were then trained to develop their supposed "innate" warlike qualities inherited from life in the Eurasian steppe, and served caliphs as highest commanders and loyal troops. They lived apart from the people as an elite corps with distinct dress, languages and customs. ${ }^{2}$ In time some such mamluk slave-turned-commanders wielded

* I thank Collegium Budapest Institute for Advanced Study for a period of Fellowship in Spring 2008 which facilitated the writing of this article.

1 The most forceful statement on this is to be found in the work of Mustafa Âlî: see especially Cornell Fleischer, Bureaucrat and Intellectual in the Ottoman Empire: the Historian Mustafa Ali, 1541-1600 (Princeton 1986) pp. 156-157.

${ }^{2}$ For the early development of the mamluk phenomenon see, for example, Patricia Crone, Slaves on Horses: the Evolution of the Islamic Polit (Cambridge 1980). 
great political as well as military power and sometimes established their own dynastic states. Slave soldiers even established sultanates by acclamation rather than on dynastic lines, as in the Mamluk Sultanate of Egypt and Syria and the Delhi Sultanate, a similar one in northern India, coming into being at about the same time in the thirteenth century. ${ }^{3}$

In addition to this model of Islamic empires, there was also a feature of tribal life in the Eurasian steppe in the background of Ottoman royal household building. This is the institution of nöker, companions of the chieftain, a group made up of individuals cut off from their original tribes and adopted into a new tribe through joining the chieftain's retinue. ${ }^{4}$ Later narrative accounts of the early, heroic but blurred Ottoman times mention Osman Bey the eponymous founder of the dynasty, though at first a very modest frontier chieftain, having a few mamluk-style slaves, $k u l$ in Turkish, among his own men and some nökers as well. As his successors enlarged their retinues, "outsiders" or "strangers" (gurebâ) was the name of one of the sections of the household cavalry, implying the continuation of the nöker-like phenomenon while a majority of household members were of kul origin.

As it fully developed, the Ottoman system of administering the realm was based on the distribution of livings (dirlik) so that the recipients could maintain proportionate official households ( $k a p \imath$ ). All sources of revenue, urban and rural, taxes, dues, fines and fees, were given out as revenue grants. The recipient of a rural revenue grant was expected to live at the source of his revenues, usually a village. Most of such rural revenue would consist of land rent for the peasant families and share of their crop, but there were also fees and fines collected in the course of keeping the peace and punishing crimes and misdemeanours. Thus the revenue grant-holder was the administrator of his area as well as serving in campaigns as a fully armed and equipped cavalryman. A revenue grant-holder of higher level of income was required to maintain out of his revenues a fully armed retainer for each multiple of the minimum allocated. A provincial official might have a dozen or so men in his retinue, a district governor bey a hundred or so, and

${ }^{3}$ See Peter Jackson, The Delhi Sultanate: A Political and Military History (Cambridge 1999); David Ayalon, Islam and the Abode of War: Military Slaves and Islamic Adversaries (Aldershot 1994).

${ }^{4}$ Halil İnalcık, 'The Question of the Emergence of the Ottoman State', International Journal of Turkish Studies II (1980) pp. 71-79. 
a governor-general pasha several hundred. The vezirs of the imperial council had revenues sufficient for thousands in their households, and the sultan's own revenue sources paid for tens of thousands. ${ }^{5}$

In addition to its magnitude the imperial household differed from others in two qualitative ways, one having to do with firearms and the other with the method of recruitment. The imperial household was supposed to have a monopoly on the use of gunpowder and firearms, only partly to be explained on the basis of the traditional royal prerogative of controlling all mining. Copper and iron mines, used in casting cannon, were included in royal revenue sources, and only the magnitude of royal revenues might be sufficient for cannon foundries and large-scale gunpowder production. But in small arms, too, the royal household jealously maintained a monopoly. ${ }^{6}$

The second distinguishing quality, a peculiar method of recruitment, is harder to explain. In all other Islamic polities, whether forerunners or contemporaries of the Ottomans, the mamluk or kul militaryadministrative slaves of the ruler had to be imported from pagan or at least non-Muslim areas. Slavic and Turkic peoples of the Eurasian steppe were the most common source in addition to captives in wars against Byzantium or the Franks, on land and at sea. Non-Muslims living within the boundaries of a Muslim political entity had the status of protected zimmi non-believers. They paid an extra jizye tax per adult male, or a lump-sum haraj tribute for the community as a whole, and in return they had rights as subjects of the ruler. They might even be exempted from certain taxation if they provided public services, individually or as a community, such as supplying food delicacies to the palace or being charged with the safety and protection of public highways, passes, and bridges. The Mamluk Sultanate of Egypt and Syria, for example, went to great lengths to ensure a steady supply of mamluk warriors from among the Qipchak Turks north of the Black Sea and from the Circassians in the northern Caucasus because their realm did not have a border against infidels except at sea, in the Mediterranean, and naval warfare was never their strong suit. The peculiar

\footnotetext{
${ }^{5}$ See n. 22 below.

${ }^{6}$ The ruler's monopoly broke down in the late sixteenth century not because of competition from other households but because muskets became readily available in large numbers to commoners who then served as seasonal or occasional mercenaries in all households (see n. 35 below).
} 
practice of Ottoman $\mathrm{kul}$ recruitment was collecting boys from among the sultan's own zimmi non-Muslim subjects.

How did this practice, known as devshirme come about? Earlier writers suggested a link with conquest and removal of young local aristocrats for palace service but that is a very different phenomenon. ${ }^{7}$ The best explanation so far is that in fact devshirme started in a frontier zone where a region open to raiding was in the process of becoming conquered territory. Most often a conquest is accomplished at a certain moment in time but on the frontier conditions could differ: a village may be raided, it may then submit, it may revert to an earlier status. It seems that frontier lords under loose Ottoman authority may have started devshirme in areas that had already submitted to them, as if they were still raiding such lands. ${ }^{8}$ Need for manpower, especially at times when the flow of volunteers to the frontier was cut at the Dardanelles crossing by enemy ships, may have lead to devshirme from areas no longer resisting. Admittedly this is speculation which will have to serve as a working hypothesis for the time being.

\section{Training to Create a New Person}

Whatever its true origins, devshirme was a much more effective way of recruitment than simply grabbing human booty during a raid because it provided an element of choosing: this is probably why it became a royal prerogative. ${ }^{9}$ Later accounts, after it had become regularized and institutionalized, talk of the devshirme process of palace officials arriving at a village and reviewing all the boys between the ages of 10 and 15 or so, young enough to be remoulded and old enough to be marched away from their homelands. The palace officer in charge would look the boys in the eye to see sparks of intelligence and honesty, for the belief was that inner qualities would be reflected in one's visage, as well as for more obvious signs of robust constitution. One in 40 boys in a given area were to be taken, not more than one from the same family, certainly not an only son. A few thousand "chosen"

${ }^{7}$ Speros Vryonis, 'Isidore Glabas and the Turkish devshirme', Speculum 31, 3 (1956) pp. 433-443.

${ }^{8}$ Vassilis Demetriades, 'Some Thoughts on the Origin of the devshirme', in: The Ottoman Emirate (1300-1389), Elizabeth Zachariadou, ed. (Rethymnon 1993).

${ }^{9}$ V.L. Menage, 'Devshirme', EI2, vol. 2, p. 210. And Menage, 'Some Notes on the Devshirme', Bulletin of the School of Oriental and African Studies 29 (1966) pp. 64-78. 
or hand-picked boys were than marched towards the capital. Further groupings were made: some were sent to royal establishments in Edirne (Adrianople) and Gelibolu (Gallipoli); of those arriving in Istanbul some were assigned to a secondary training centre in Pera. The select few, numbering several score, finally arrived at the Topkapi imperial palace. Along the way they became Muslims and were given new Muslim names. They all shared the common patronymic Abdullah, literally servant of God.

The newcomers were assigned to two halls in the innermost courtyard of the palace known as the Big Chamber and the Little Chamber simply for their size. These two chambers were for basic instruction under the general supervision of the white eunuchs (as opposed to the black eunuchs of the Harem, the women's quarters). After a few years of book learning from invited tutors and physical training by the white eunuchs the palace pages moved on to chambers where further study and training was combined with practical service to the sultan. Names of these chambers, lining the third court, reflect the kind of service: those in the Pantry Hall helped in the bringing and distributing of food from the palace kitchens; the Campaign Hall pages were involved in wardrobe, linen, and laundry duty as well as packing for campaigns and hunting excursions; the more senior pages in the Treasury Chamber served in preserving and securing valuables, cloth, books, and jewels. The highest and most senior group was in the Privy Chamber in charge of the Inner Sanctum of Holy Relics (of the Prophet and earliest caliphs); the two most senior pages served as the sultan's sword-bearer and cloak-bearer. During their time in the Inner Service (enderûn) the pages were always under the supervision of the white eunuch officers who directed their education, training, and practical service.

Then came graduation, chikma, literally "leaving", the first of a series. From the third (inner) court some of the enderun pages moved out through the Gate of Felicity to the second and first courts for Outer Service (bîrûn). One should not envisage a "palace school" although it has been called that; not all pages moved from level to level and on to graduation. ${ }^{10}$ A page could be asked to leave when he was deemed to

${ }^{10}$ Barnette Miller, The Palace School of Muhammad the Conqueror (Cambridge, Mass. 1941). The most comprehensive studies of the palace and imperial household remain the works of İsmail Hakkı Uzunçarşıll, Kapıkulu Ocakları [Household Troops] (Ankara 1943) and Osmanlı Saray Teşkilâtı [Ottoman Palace Organisation] (Ankara 1945). 


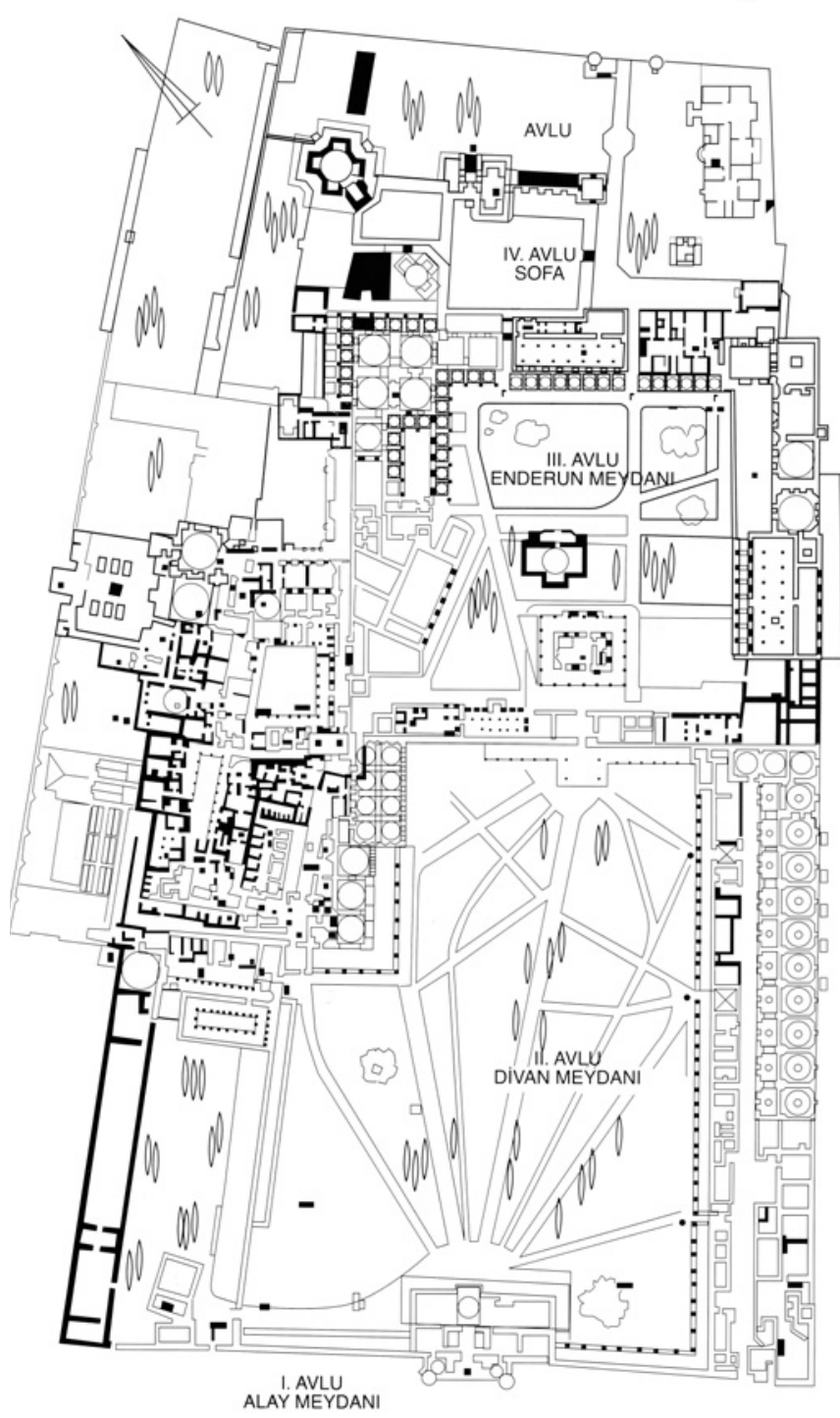

II: Second, outer court (bîrûn), including the Chamber of the Imperial Council with the Imperial Treasury right next to it on the upper left (NW corner) and kitchens along the right $(\mathrm{E})$.

III: Third, inner court (enderûn). Facing the gate between the outer and inner courts is the Audience Chamber, with halls for the pages along the sides of the court.

The women's harem, a 16th century addition, straddles the two courts on the West side. The Fourth Court (IV) is gardens with pavillions added in the 17th c.

Simplified from Deniz Esemenli, Osmanlı Sarayı ve Dolmabahçe, (İstanbul, Homer Kitabevi 2003); by kind permission of author and publisher.

Figure 1. This map shows the main parts of the Topkapı Palace, leaving out the first, public, court (I). 
have reached the end of his capacity for learning or for personal service to the sultan or when he himself preferred to. Some left, or "graduated" after the course in the Big and Little chambers, others after a few years of service in the Pantry, Campaign, or Treasury chambers. They took up salaried active offices in the Outer Service, their ranks depending on how long they had stayed in the enderûn. There they served as gatekeepers or groundsmen, supervising the kitchens or the stables or the tentsmen and bannersmen (including the mehter marching band), as message runners, or special guardsmen; most joined the six sipâhi elite household cavalry regiments and a few might even be assigned as officers to the various divisions of lower-ranking household troops, infantry, armourers, artillerymen, etc., which were all made up of kul recruits less privileged than the enderûn pages. Some pages of a bookish disposition might receive an appointment in the palace scribal service, chancery or treasury; those with an artistic bent developed their talents and crafts in palace studios and workshops as painters, calligraphers, gold- and silversmiths. At least in the sixteenth century there was no clear-cut distinction between the learned or artistic individuals and those with military qualities; those who wielded the pen or the painter's brush would be expected to be adept with the sword as well, as we know from numerous examples of household cavalrymen or gatekeepers co-opted to book production (one even from the artillery corps) and, conversely, scribes ultimately getting provincial administrative office.

Outer Service officers may have had high rank but essentially they were still in service to their master the sultan directly and were paid by him in salary and expenses. A second graduation or leaving was for independent office with an independent source of income, a "living", a revenue grant; this was when they really started their career ladder. This time palace people left through the Imperial Gate for the outside world. In the sixteenth century a palace officer might hope to gain a provincial post below a district governor but certainly superior to and sometimes supervising basic revenue grant-holders. Ordinary household troopers, too, hoped to receive a provincial revenue grant, but their "living" would be at a much lower level. A few of white eunuchs who had been supervisors and tutors in the enderûn might also leave at this point, directly gaining higher provincial office, commensurate with the length of their service. Not much is known about how these supervisor eunuchs were recruited. Judging by the fact that the Chief White Eunuch was the head of the Inner Service 
and thus the highest ranking palace official, furthermore that some at least attained the highest offices in the realm, even-almost routinelybecame grand vezirs, they may have been ordinary devshirme recruits who volunteered for castration to prolong their palace careers and to obtain provincial office at the highest possible rank. ${ }^{11}$ We now know that Gazanfer Agha, perhaps the most illustrious Chief White Eunuch who, however, never held outside office was a Venetian; he underwent castration to enter palace service where he rose to become one of the most important figures in the politics of his time. ${ }^{12}$

Palace service, then, prepared the kul recruits for provincial office where they joined others from a purely provincial background, some of them indeed of Turkish stock. Theirs was a military-administrative career; they were now ümerâ commanders. ${ }^{13}$ They were expected to work as administrators alongside and cooperating with kâd $\imath$ magistrates from a different educational background, the madrasa colleges, and who had an entirely different career line as ulemâ men of learning (of theology and law). By the rationale of their career the ümerâ officers were also soldiers; at campaign times they mobilized the revenue grant-holders of each district under its banner and joined the sultan's campaign, paying for their own expenses out of their "living". Those ümerâ who distinguished themselves in the provinces and on campaign became district governors; about twenty out of 200 or so sancakbeyi district governors were later promoted to the rank of pasha and served as province governors. A handful of the most distinguished province governors were invited to join the Imperial Council which met at its hall in the Second Court of Topkapı Palace. Although there were Turkish ümerâ and other revenue grant-holders in provincial administration some of whom rose to district governor, in the sixteenth century almost all the pashas and the vezirs of the Imperial Council were of $k u l$ origin and had been trained at the palace. Those

${ }^{11}$ White eunuchs (hadim) who eventually held high office are too numerous to mention but those who became grand vezirs in the sixteenth century are Hadım Ali Pasha, a Bosnian, grand vezir in 1501-1503 and also 1506-1511; Hadım Sinan Pasha, a Bosnian, gv in 1515 and also 1516-1517; Hadım Süleyman Pasha, origin unknown, gv in 1541-1544; Hadım Mesih Mehmet Pasha, origin unknown, gv in 1585-1586; Hadım Hasan Pasha, origin unknown, gv in 1597-1598.

${ }^{12}$ Maria Pia Pedani, 'Safiye's Household and Venetian Diplomacy', Turcica 32 (2000) pp. 9-32.

${ }^{13}$ I. Metin Kunt, The Sultan's Servants: The Transformation of Ottoman Provincial Government, 1550-1650 (New York 1983) chaps. 3 and 4. 
few who became vezirs thus returned to the familiar surroundings of Topkap 1 for council meetings in the Second Court after an absence of perhaps 15 or 20 years.

\section{From the Father's House to the Son's Household}

Palace service, both in the Inner and Outer Courts, had a special ethos. The concentration of such large numbers of men in the confines of Topkap1 required that pages, servitors and troopers behave with decorum, respect, and above all maintain an almost monastic silence..$^{14}$ Etiquette aside, the most important fact about the palace was that people there spoke many different languages. In this veritable Tower of Babel Turkish was the common language but people's original tongues, no less than their original names and family backgrounds were never forgotten. In his conversion from peasant boy to enderûn page a Petro son of Dimitri may have become Davud bin Abdullah but this happened at an age when his mother tongue was already firmly a part of his person. As at any public school nicknames abounded, some of which, Apostol and Vasil for example, alluded to the "previous" person. ${ }^{15}$ Nicknames were particularly useful in the palace because in their refashioning there seems to have been a limited store of names. There were Muslim names: Mehmed, Mustafa, Ali being the most common. Another source was the Bible or, more correctly the Muslim form of Old Testament names: Davud (David), Yahya (John), and of course Süleyman (Solomon). The Iranian Shahname was another source of inspiration with Iskender (Alexander) and the great heroes Rüstem and Behram. To distinguish the various Mehmeds at any one time some were "the tall", some were "the blond", some "the ox" (was he particularly strong or dense? one wonders).

These new Mehmeds and Davuds and Iskenders were now all Muslims, some no doubt very devout, but their Islam could be peculiar to them. In the seventeenth century there was word of a group of

\footnotetext{
${ }^{14}$ Alan Fisher and Carol Garrett Fisher, 'Topkap1 Sarayı in the mid-Seventeenth Century, Bobovi's Account', Archivum Ottomanicum 12 (1987) pp. 5-81.

${ }^{15}$ For example Mahmud/Apostol, pp. 220-221, and Halil/Vasil, p. 265, both Janissary commanders, in Selâniki Mustafa, Tarih [History], Mehmed İpşirli, ed. and transcription (İstanbul 1988).
} 
hub-mesîhi Christ-lovers in the Inner Palace. ${ }^{16}$ Most pages went on to serve in the six prestigious cavalry regiments; for the general lowerranking household troops dervishes of the Bektâshi order served as chaplains. This sûfi mystic devotional order takes its name from an Anatolian sheyh of a much earlier age but as an order it was the recent coalescence of various syncretic movements. ${ }^{17}$ Like the Shi'is the Bektâshi venerated Ali but some of their beliefs and symbolism call to mind a trinity (of God-Muhammad-Ali) with twelve being a special number and the dove a special creature. Their rituals included partaking of wine (in various quantities). This was an ideal religious outlook, then, for a new Muslim, a convert from Christianity. Bektâshism was of course strong in Anatolia, its birthplace, but it grew even stronger as it spread in the Balkans, especially Albania, and into Hungary, wherever there was large-scale conversion to Islam. As opposed to Bektâshism, if the enderûn page and by extension a sipâhi of the six cavalry regiments was of a siff bent he would most likely become a Mevlevi, a relatively urban and sophisticated order much involved in musical and literary arts, also noted for its tolerant view of religiosity.

Belonging to a particular order may have strengthened their new identity, but as in any confined institution of people there was cliquishness as well. ${ }^{18}$ Groups were naturally formed along linguistic or ethnic lines and included more senior and incoming pages as well as their connections in the Outer Service. One of the most fascinating documents I ever came across in the Topkapi Palace Archives is a short little note, undated (but of the sixteenth century) and unsigned, reporting the information supplied by another. ${ }^{19}$ It simply says that in a particular village in Bosnia there is a particular family with three sons and the youngest son is very bright. The inevitable conclusion, to my mind, is that somebody (a white eunuch supervisor?) asked enderûn pages about their own villages and for recommendations for devshirme

\footnotetext{
${ }^{16}$ Ahmet Yaşar Ocak, Osmanlı Toplumunda Zındıklar ve Mülhidler [Atheists and Miscreants in Ottoman Society] (İstanbul 1998) pp. 228-230.

17 Ahmet Karamustafa, God's Unruly Friends (Salt Lake City 1994); also 'Kalenders, Abdals, Hayderîs: The Formation of the Bektashiye in the Sixteenth Century', in: Süleyman the Second and His Time, Halil İnalcık and Cemal Kafadar, eds. (İstanbul 1993).

${ }_{18}$ Metin Kunt, 'Ethnic-Regional (cins) Solidarity in the Seventeenth-Century Ottoman Establishment', International Journal of Middle East Studies 5, 3 (1974) pp. 233-239.

${ }_{19}$ Topkapı Palace Archives, E.9607.
} 
recruitment. Was this recommendation acted upon? Impossible to know, but the important thing is that the question was asked at all and a reply given. Alongside such informal groupings based on ethnicity or educational bent or religiosity it is astonishing that there were high palace officials who had their own kul in the palace. I have in mind a Cafer Agha, Chief White Eunuch, the Director of the Inner Service, who left behind at his death in the mid-sixteenth century, among other property, a group of owned slaves some of whom were in the palace. This we know because the sultan inherited Cafer Agha's property (as, obviously, he died without issue) and decreed that the rest of Cafer Agha's kul should be also incorporated into palace service. The curious conclusion is that not all in the palace were the sultan's own slaves; some owed direct loyalty to another master. ${ }^{20}$

Such connections formed while at the palace, formal or informal, may have played a role in the chikma graduation movement, helping determine who got what posting. Graduation occurred at irregular intervals; Outer Service officers and troopers went off to the provinces, Inner Service pages took up postings in the Outer Service, new recruits were brought in both to the enderun and to the various bodies of household troops. Some of these occasions were termed "lesser" graduations when relatively few people moved on but at "greater" chikma thousands of people may have been involved. Such was the case especially at the death of a sultan and the enthronement of one of his sons. This was true in the fifteenth and sixteenth centuries when princes were traditionally sent out of their father's palace as district governors; whoever survived the struggle for the throne returned to the capital in triumph. ${ }^{21}$ From the turn of the seventeenth century this custom was allowed to lie fallow but enthronement still entailed graduation for the coming of a new sultan, whether from the provinces or emerging from the shadows in the palace itself, meant the taking over of the palace, making his father's people his own. For this purpose the new sultan gave out the traditional "accession gratuity" to his palace servants, and promotions and salary increases to many independent

${ }^{20}$ Ottoman Archives, KK 4990. I analyzed this list in 'Kulların Kulları' [Slaves of Slaves], Bosporus University Journal-Humanities 3 (1975) pp. 27-42.

${ }^{21}$ This is not the place to go into a discussion of Ottoman succession; suffice it to say that there was no method of succession, no seniority, not even a pre-designated heir, except that succession was from father to one of his sons (and not to any other member of the family), the one who had the political and military nous to defeat the others if it came to that. 
office- and revenue grant-holders. In one sense the new sultan started things anew although in another he took pride in being the scion of an illustrious dynasty: he was a new link in the dynastic chain, a basic element in his legitimation as ruler.

An Ottoman prince grew up in his father's house and, before he was confined to the palace from around 1600, went out to a provincial posting, usually upon puberty and after being circumcised, when he took his first steps to adulthood. ${ }^{22} \mathrm{He}$ was now a district governor, a sancakbeyi, one of perhaps two or three hundred such ümerâ commanders, but the revenues assigned to him could be more than given a grand vezir. While a vezir might keep a household of one thousand men or more, a prince-governor's household was much more modest. At his "graduation" from the palace his father the sultan gave the prince his initial household out of the imperial palace; the occasion was not really a graduation for the palace people assigned to the prince, on the contrary they might feel that they were demoted from the secure existence of the palace to an unsure future with one of the princes. But in any case the people were imperial property, so to speak. If "their" prince eventually won the throne struggle they would come back to Topkapı in his retinue. Even if he lost they would not be punished unless they were in the prince's inner circle; they would be taken back into the imperial fold. The numbers involved were not even close: there were tens of thousands attached to Topkap1 whereas the prince's initial household numbered around five hundred. ${ }^{23}$ The political advisors assigned to the prince were high-ranking pashas; being with a prince for a number of years was but one step in their career ladder although there might develop covert alliances between certain pashas and particular princes.

Up to this point I have been talking in generalities, presenting a somewhat idealized picture, routines rather than rough edges; it is now time to become more specific and explain the problem of "Turks in the Imperial Palace!". I have in mind two instances of change of sultan:

${ }^{22}$ Metin Kunt, 'A Prince Goes Forth (Perchance to Return)', Identity and Identity Formation in the Ottoman World, Karl Barbir and Baki Tezcan, eds. (Madison Wis. 2007) pp. 63-71.

${ }^{23}$ For an estimate of around 36,000 in and attached to the imperial palace in the mid-sixteenth century: Halil İnalcik, The Ottoman Empire: The Classical Age, 13001600 (London 1973), (several hundred in the Inner Service and the rest in Outer Service and in various regiments of household troops), pp. 80-83; for Prince Mehmed's household of less than 500 in 1541: Topkapı Palace Archives, D.9706/3. 
the accession of Selim II on Sultan Süleyman's death in 1566 and the accession of Murad III in 1574 on Selim's death only eight years later. Selim's accession took place under very unusual circumstances because his aged father died on campaign in faraway Hungary, besieging the obscure but problematic stronghold Szigetvar, and this story is wellknown. The second aspect of Selim's unusual accession has to do with his inordinately large princely household and how "graduation" and "integration" were handled. Murad's accession eight years later was routine by comparison. Both events are well-documented, in extensive narratives for 1566 and in a unique document for 1574 which details the prince's household and how exactly it was to be integrated into Topkapi. Both stories are extremely important for trying to answer basic questions: how did the Ottomans conceive their political structure? What was their idea of the "state"? Was there an evolution of state institutions aside from the instruments of the dynastic state?

\section{Accession of Selim II}

Sultan Süleyman had five sons, two of whom died of natural causes. ${ }^{24}$ The sultan had his oldest son executed in 1553 when he became suspicious that Prince Mustafa might have designs on the sultanate. Five years later the younger of the two remaining princes, Bayezid, feared that his older brother Selim was more advantageously positioned in his provincial posting for a quick dash to Istanbul at the death of Süleyman, now well-advanced in years and suffering from gout and possibly other infirmities. The father tried to reassure Bayezid of his impartiality but the prince, his fears unallayed, started to recruit an army for a show-down with Prince Selim to pre-empt the issue of succession. Suleyman had no choice but to support Selim against Bayezid, by now considered a rebel. Prince Selim, too, recruited Anatolian peasants for an army; bolstered by imperial troops and able commanders seconded to his service he defeated the rebel prince. Bayezid sought refuge with the Safavi Shah Tahmasb but having recently concluded a peace the two rival empires were on relatively amicable terms and Shah Tahmasb eventually had the rebel prince and his sons killed (for which he gained the gratitude of and substantial gratuity from both

\footnotetext{
${ }^{24}$ Alan Fisher, 'Süleyman and his Sons', in: Soliman le Magnifique et son temps, Gilles Veinstein, ed. (Paris 1992) pp. 89-104.
} 
Sultan Süleyman and the surviving prince) ${ }^{25}$ Prince Selim the lone survivor now just had to sit comfortably and wait for life to continue on its course.

Süleyman's death may have been long-anticipated but it finally came eight years later when at age 72 and infirm he went on his last campaign in Hungary. ${ }^{26}$ His troops were about to conquer the frontier stronghold Szigetvar when he died. How Prince Selim succeeded to the throne and how he was enthroned twice, once in Istanbul where he hurried upon receiving the news of his father's death and once outside of Belgrade where he eventually took over the imperial household, is an interesting and illuminating story I studied elsewhere for the clues it provides to understanding the Ottoman political order. For my present purpose the more relevant aspect of Selim's accession is the uncertainties surrounding the general palace chikma graduation occasioned by the coming of the new sultan and the integration of the prince's household into the imperial palace. This process would have been routine at any other time. As a prince in 1520 Sultan Süleyman himself had a total household, Inner and Outer, of several hundred, a small number compared to the thousands in the palace organization. The problem in 1566 was that Selim had a conscript army of about eight thousand formed eight years previously to fight his rebellious brother: how were they to be integrated into the system? What palace people and who of the prince's retinue were to receive which appointments?

A game of musical chairs (sofa cushions in the Ottoman context), a scramble for offices started as Selim was speeding from his provincial seat in Kütahya to Istanbul. ${ }^{27}$ On the way, the day after he learned of his father's death, some of his courtiers and princely retinue pleaded for imperial office; it is an indication of the elderly prince's perception of Ottoman ways that he responded with irritation that he hadn't even sat on the throne, that it was too soon to grant their requests, and that in the glorious past of his ancestors no service went unrewarded. There was friction when the prince and his small retinue reached the palace.

${ }^{25}$ Rhoads Murphey, 'Süleyman's Eastern Policy', in: Süleyman the Second and his Time, Halil İnalcık and Cemal Kafadar, eds. (İstanbul 1993) pp. 229-248.

${ }^{26}$ The main contemporary and eyewitness Ottoman narratives of the events surrounding Sultan Süleyman's death are to be found in Feridun Bey, Nüzhetü'l-esrâri'lahbâr der sefer-i Sigetvar [The inside story of the Szigetvar campaign], Topkapı Palace Library, MS H.1339, an unabashed apologia for Sokollu Mehmed Pasha; and Selâniki Mustafa, Tarih, vol. 1, who wrote his history later in his life.

${ }^{27}$ Selâniki, Tarih, p. 41. 
The prince's equerry prepared his horse in the palace grounds for him to ride up from the shore but palace people wanted to take over. The equerry was not a "palace product", they objected: he wouldn't know how and where to lead the horse. It wasn't simply a question of knowing the palace grounds; it was also a matter of palace decorum. The prince asked the Chief Groundsman to show his equerry the way so that the officials had to co-operate, if grudgingly. ${ }^{28}$

When the prince eventually heeded the grand vezir's advice to go to meet the returning imperial army for the process of succession to be completed there was much more serious trouble at the camp outside of Belgrade. The janissaries noted that some of the prince's Anatolian conscripts accompanied him. Accession to the throne was the time for promotions, salary increases, and graduation to independent revenue grant: how was the prince going to accommodate both the imperial household and his Anatolian men? Worried that they might be shortchanged, since the new sultan made no explicit reference to their satisfaction, they raised their voices and listed their demands: campaign bonus as well as accession gratuity; they were especially incensed after hearing that these conscripts had already been housed in their barracks while in Istanbul. "That uncouth lot who accompanied the prince should not mingle with us or else we will kill them like dogs" is how Selâniki reports their words. ${ }^{29}$ There were fisticuffs and daggers were drawn; some Anatolians were killed. Sultan Selim in the end acceded to the financial demands of the household troops in order to be able to keep his promises to reward the recruits who helped to defeat his brother in 1558. But the troubles were not over: Selim's recruits were ex-peasants; provincial revenue-grant holders in the army recognized some of them among the sultan's men, some indeed now grant-holders themselves. They demanded peasant dues from such men as being their registered peasants. The sultan ruled that the revenue grants which suffered because of losing peasants should be compensated from revenues not previously registered; otherwise the ex-peasants were confirmed in their new appointments. He felt that he had to justify his action in the face of opposition, sullen as well as loud, by saying, as reported by Selâniki, that he was simply following his

28 Selâniki, Tarih, pp. 42-43.

29 Selâniki, Tarih, p. 51. 
father's orders in 1558 to form an army from Anatolian "horse-riding, weapon-handling" peasants just as his rebellious brother had done. ${ }^{30}$

In 1566 there were 12,000 janissaries at the Szigetvar campaign, according to Selâniki. ${ }^{31}$ As many as 2,000 had been sent on a different campaign at the other end of the empire, included in a task force to put down a rebellion in the marshlands near Basra. There were also janissaries stationed in some major cities. But Rhoads Murphey has concluded that at the end of Selim's reign eight years later there were more than 21,000 janissaries. ${ }^{32}$ Most of the huge increase in janissary numbers came from the incorporation of peasant recruits from the princely army. According to Murphey's numbers, the total pay to janissaries increased from about 20 million akches in 1547 to about 35 million in 1567. Even taking into consideration a possible limited increase between 1547 and the end of Süleyman's reign, the burden to the sultan's treasury was increased by about half. But the problem was not only financial for there were also considerations of "proper" recruitment into the imperial palace. Selâniki notes that the palace personnel given to a prince when he first went out to provincial office normally returned to positions in the palace when their prince succeeded. In Selim's case, the historian adds, 350 men went out of the palace but 8,000 loutish, unschooled men came to Istanbul with him, many of them no better than thugs (I soften the historian's words, he says "common criminals and murderers"). ${ }^{33}$ The epithets used by each group about the other point to a vast gap in service ethos and group solidarity. But two senior commanders of household troops and several troopers were executed when first they remonstrated too vociferously with the grand vezir about the "Anatolians" coming into the palace guard, their protests leading to mutinous disorder.

In the palace itself, the Campaign Hall was emptied and pages from other Halls too were "graduated" for Kütahya pages to come to Topkapi. As for senior officials, some of Süleyman's leading servitors were given the option of sinecures and retirement to make room for men from the princely court. These men, according to older palace officers, were not the products of the palace itself and were therefore deficient in their understanding of the palace ways. "Outsiders" is the

${ }^{30}$ Selâniki, Tarih, pp. 56-57.

${ }^{31}$ Selâniki, Tarih, p. 51.

${ }^{32}$ Rhoads Murphey, Ottoman Warfare (London 1999) pp. 42-44.

${ }^{33}$ Selâniki, Tarih, p. 58. 
least they were called. ${ }^{34}$ In higher echelons, too, there was a conception of the "proper" way of doing things, of recruitment into household troops. There was also a generally acknowledged principle at work, that "subjects should remain subjects" and not switch to the ruling group, not least because it would lead to diminishing of subject dues. It was certainly not impossible for the son of a subject to gain his way into the military-administrative elite; social mobility was not totally stifled, but there were accepted ways of doing this. A Muslim Turk could go to the madrasa colleges and eventually become a $k a \hat{a} d \imath$ magistrate; native wits and patronage would help. Or, if his bent was military rather than bookish as was likely, he could attend imperial campaigns when it was announced that any young volunteer would be rewarded for valiant service. Normally his reward would be a revenue grant but never inclusion into the imperial household.

It would be in order to ask whether the decision in 1566 to include Anatolian peasant-mercenaries in the imperial household could have been based on military considerations. To support this view we may recall that the Habsburg ambassador Busbecq reported that as early as the 1550s the grand vezir Rüstem Pasha tried to train the household cavalry in the use of muskets..$^{35}$ Although the Ottoman military ethos was not nearly as conservative as that found in the main Mamluk and Safavi armies, firearms were still looked down upon. In the event the cavalry, a superior corps, rejected musket training (the whole gunpowder business was too dirty and unseemly), and the idea was dropped. If there was a perceived military need for a musket-bearing cavalry force and the household cavalry refused to adopt to changing needs, why did Selim justify himself by referring to his father's orders eight years previously? Could he not have formed the Anatolian mercenaries into a separate and special troop?

The interesting thing is that there was still an Anatolian military organization, first formed in the mid-fourteenth century, at a level below the revenue-grant holding provincial cavalry. They were not supported by taxes and fees collected from the peasants but held land and were tax-exempt; essentially they were privileged farmers, considering military service as a privilege in the Ottoman conception of

${ }^{34}$ Selâniki, Tarih, pp. 59-60.

35 C.T. Forster and F.H. Blackburne Daniell, trans., The Life and Letters of Ogier Ghiselin de Busbecq I (London 1881) pp. 242-243. 
polity and society. Some of these farmer-soldiers were infantry and some cavalry. Before the Ottoman ruler formed and expanded his own retinue of janissary infantry and the household cavalry the peasant infantry (yaya) and cavalry (müsellem) had an important military function. This organization existed only in western Anatolia, the initial heartland; they were never installed in the Balkans where akıncı frontiersmen and non-Muslim martolos tax-exempt peasants performed a similar function. In the mid-sixteenth century the Anatolian yaya and müsellem still existed on paper as military groups but by then such auxiliary troops were in terminal decline, their effectiveness long eclipsed by household troops, both imperial and grandee retinues. Could such men have been assigned to Selim to fight his brother in 1558? When Selim referred to his father's ferman he quotes "your brother raised mercenary troops (yevmlü, lit."on a daily wage"), you should do the same and raise in your area yevmlü troops of horse-riding, weaponhandling peasants". Some peasants, then, good on horseback and with weapons' practice, were already deemed more effective as mercenary soldiers than the tax-exempt peasant-soldiers of yesteryear. Indeed, in the decades to come the revenue-grant holding provincial cavalry too declined to the status of auxiliary troops, though in typically conservative Ottoman fashion they were not abolished until well into the nineteenth century.

If the idea of household troops was to have a standing army which could be regularly trained in weaponry, effective musket-firing in ranks, and group maneuvers, and if, in addition to the janissary infantry there was need for a musket-bearing cavalry, would Selim's Anatolian mercenaries have served that purpose? Though muskets are not specified among the weapons they "handled" they are referred to as sekbân when they first came to Istanbul from Kütahya and were housed in the empty janissary barracks: the significance of the term is that it was used later for Anatolian mercenaries employed extensively during the long Habsburg and Safavi wars at the end of the century. ${ }^{36}$ On the other hand, horse-riding they might have been, but Selim's mercenaries were incorporated into the janissary corps and not into the elite cavalry regiments: that would have been unthinkable. Once in

${ }^{36}$ Selâniki, Tarih, p. 29 refers to "musket-bearing sekbân and hunters in grandee households" at Szigetvar; unless this is an anachronism or a case of his old-age memory failing the author, the employment of sekbân mercenaries must have been earlier than hitherto presumed. 
the janissary corps, though the regular janissaries gave them the cold shoulder to say the least, they never constituted a special unit and the need for musket-bearing cavalry was met by employing mercenaries seasonally and as needed by campaigns. All in all, my conclusion is that Selim did not act with any long-term military need in mind but simply kept his promise to the mercenaries who helped him defeat his brother and secure his eventual succession.

\section{Accession of Murad III}

More "outsiders" were to come just eight years later when Selim died and his son Murad succeeded to the throne. This time there was no crisis of numbers for Murad's court in Manisa employed about 1,800 men, a large number for a princely retinue but minor in comparison with Selim's recruit army. In this case a document was prepared for the attention of the new sultan listing all members of the Manisa retinue for the sultan to decide how they were to be placed. This whole process is interesting for it shows what principles were commonly accepted as "ancient law and usage". ${ }^{37}$

Five senior officers of the princely household were taken into the palace with pay increases but at lesser imperial ranks compared to their office in Manisa; some 35 lower officers were given revenue grants. The document goes on to list different sections in the household and for each section differentiates groups according to seniority of service to the prince during his 18 years as governor. The senior service, so to speak, was the cavalry, divided into four regiments bearing the same names as in the imperial household (where the last two were divided into right-hand and left-hand regiments, making six altogether), in order of prestige the sipâhi, the silahdâr, the ulûfeci, and the gurebâ. Each of the four regiments was considered in six groups in order of longevity in the prince's service: some since his first appointment as governor in 1558, some who graduated from the palace and had been sent to the prince's court, those who joined after the prince was transferred to Manisa in 1564, those taken into regiment sometime later, and finally those who were promoted to the regiment after the prince's succession but before the Manisa household was transferred

\footnotetext{
${ }^{37}$ Ottoman Archives, MAD 1324.
} 
to Istanbul. Further details would be interesting for Ottomanists and I may provide them elsewhere but here I will make some general observations. The top two groups in each regiment were incorporated into one lower imperial regiment, the rest to the next lower regiment: of the prince's sipâhi the top two became imperial silahdâr, the next two became imperial right-hand ulûfeci and the last two became lefthand uluffeci. This pattern is repeated for all the regiments until the last regiment, the gureba who joined the same imperial regiment. To give an indication of numbers involved, the prince's four regiments totaled 389 men (of whom, however, by far the largest was the top sipahi regiment with 230 men); they were included into the imperial regiments that totaled just under 6,000 . Some of them were given the option of a provincial revenue grant. All in all the incorporation of the Manisa court into the imperial palace was not a troublesome business, especially compared to the ugly situation in 1566. Unlike Selim's, Murad's retinue conformed to the pattern of a "normal" princely court, that is to say without any infantry, thus it did not present a problem for the janissaries. The superior standing of the imperial palace was acknowledged and affirmed once more and the relatively few men who came into the various imperial corps did not cause disruption, or at least none worthy of note in the histories.

There was a problem, however, of a different nature: there were a significant number of last-minute promotions into the prince's more senior regiments, and some people were even taken into the household after the prince's succession. At the imperial council the argument was put forth that upon succession the prince's accounts became part of the central imperial treasury, and therefore his chief of finance was out of order when he took on more people and authorized various other payments. The princely treasurer Kara Üveys was reprimanded but escaped further punishment, perhaps at Murad's request; sometime later Murad appointed him the imperial Chief of Finance, perhaps as part of his programme of reasserting arbitrary sultanic power over bureaucratic principles. ${ }^{38}$ Here, I think, we can detect an important political principle being established and observe that there was a government in the budding, an administrative institution separate from the will of the sultan. As with most Ottoman developments it is far

${ }^{38}$ Selâniki, Tarih, p. 112. 
from being unambiguous. What the grand vezir argued, with the concurrence of the rest of the imperial council, was the supremacy of the imperial household itself; yet, by extension, it was for the central ministers to administer the affairs of the palace. Indeed, one can make a strong case that especially from the later decades of Süleyman's reign, there was an evolution towards a government with established procedures where the sultan himself went along with usage-to-becomeancient-custom. For example the vezirs of the council were ranked from the first, the grand vezir, through the second down to the seventh. When the grand vezir died or was dismissed they all moved up one seat so the second vezir became the grand vezir. Usually the Governor of Rumeli was promoted to the council as the new seventh vezir, and the second most senior governor, of Anatolia, became the Governor of Rumeli. In a system which worked almost automatically, where was the will of the sultan? If he was sufficiently interested he could decide who should be the new Governor of Anatolia, usually on the recommendation of the grand vezir. In terms of policy-making, too, the sultan nominally had the last word but it was the grand vezir's vision that determined options and recommendations.

I have been speaking in general terms: there was also a specific grand vezir who took full advantage of the procedures and vezirial power that Süleyman had allowed to emerge, the last grand vezir of Süleyman, Sokollu Mehmed Pasha who went on to serve through Selim's reign and during Murad's first five years as well, for fourteen years altogether until his assassination in 1579. After that Murad asserted the arbitrary power of the ruler, as opposed to "established usage and custom", when he changed and promoted his vezirs at will, played them against each other and never allowed one to become paramount as Sokollu Mehmed Pasha had been. What Murad nipped in the bud was certainly not a constitutional development, perhaps not even an institutional one: Sokollu was not one to share vezirial power with the council willingly, the size of his own household and his extensive nepotism and patronage was legendary. Cemal Kafadar rightly recalls Cardinal Richelieu in this context, and not a "prime minister". Yet Sokollu's way would have led to ministers with departments and a restriction of the role of the palace; in any case it would have been a different development, but it's no use thinking about what did not happen. Ottoman writers themselves thought at the time that the "debasement" of palace procedures was a much more important point. 


\section{Toward a New Palace}

So in 1566 at Selim's accession Turks came into the imperial palace in large enough numbers that the way of the janissary was forever changed. This coincided with growing problems, financial, military, and political, which gathered momentum to reach a crisis point by the end of the sixteenth century. Ottomanists have long given up starting an inexorable Ottoman decline from then, a patently ludicrous notion given that the empire survived to the Great War in the twentieth century. The crisis, however, was real. Many Ottomans at the time wrote about what had gone wrong. Prominent among various reasons they cited was the deterioration of the imperial household. Looking back to the period it is clear that there developed a fierce competition for military and administrative appointments in the Ottoman system by the middle of the century. Already around 1540 Sultan Suleyman had to issue an edict on how revenue grants were to be assigned because those holding grants did not want any "outsiders" coming into their midst, expressions echoed during the janissary reaction of 1566 . The provincial cavalry wanted to keep the revenue grants in the family, for their sons to succeed them. Süleyman's ferman in response bears close scrutiny: in the preamble the sultan asks, "how can anybody within my domains be considered an outsider?" Whether revenue grantholders or members of households or plain subjects, you are all my $k u l$ servitors, he goes on to say. This is a significant broadening of the sense of "servitor" from his household servants to include all officeholders and subjects. The rest of the ferman is devoted to who among descendants of grant holders could be given livings, under what conditions and circumstances, keeping the group open to newcomers. ${ }^{39} \mathrm{~A}$ similar profusion of candidates for ulemâ judicial-educational offices was also experienced, with madrasa college students without hope of appointment spending longer periods as professional students at their endowment-supported colleges. Employment in households, too, was becoming hard to come by. Murad's list of his Manisa household members is replete with marginal comments on many of his officers, "taken into the household on the recommendation of thus and so". Ottoman subjects could certainly make a living outside the ulemâ and ümerâ careers, but having a foothold in a household would guarantee

\footnotetext{
${ }^{39}$ Kunt, The Sultan's Servants, p. 38.
} 
change of status from ordinary subject to member of the ruling elite with all the tax exemptions and other privileges it brought.

This was a social order where somebody with an appointment certificate was deemed to have higher status than the richest merchant. Lütfi Pasha, the grand vezir dismissed in disgrace who turned to scholarship in retirement, wrote in his history with approval that when the burghers of Bursa came in their holiday best to greet the sultan visiting their city, Süleyman was cross and told them such fineries should be for officials only, not merchants. ${ }^{40}$ The pressure for official employment inevitably reached the imperial palace itself. As in other grandee households, Topkapı started to admit free, Muslim-born youth on recommendation. Judging by the careers of some such Turks reaching high office in the early decades of the seventeenth century this practice must have already started in the sixteenth century. With so many candidates for household service devshirme was no longer needed. There were intermittent instances of it during the seventeenth century but more as a result of calls for a return to the good old days before the time of troubles, exceptions that prove the observation that it had been, in effect, abandoned.

It does not follow, however, that the palace turned Turkish. Certainly there were Turks trained and schooled in the Inner Court and in growing numbers. There were also many Albanians, Bosnians, Circassians, Abkhaz, Georgians, and some European captives or volunteers, but we no longer find the young sons of Christian subjects. The enderûn was not meant to be composed of the peoples of the empire; its purpose was not to create a mingling of the empire's ethnicities to be representative of its peoples, but simply to train officials loyal to the sultan. This it continued to do although its conditions were changed in more ways than one. Palace "pages" tended to spend longer in palace service; they were not young men but getting on in years. Because they tended to spend many years in the same Hall, solidarity based on service tended to strengthen. Informal groupings based on common origin or common interest, too, gave the place a certain "clubbishness" (if I can make up a word). When eventually they went out on graduation, a few senior "pages" got high office, typically directly as province governors, and many others formed their first official household based on

${ }^{40}$ Lütfi Pasha, Tevârih-i Âl-i Osman [History of the House of Osman] (İstanbul 1922) p. 382. 
connections and relationships formed during the long time spent in the palace. As the devshirme had not made a connection between the palace and the subjects, except incidentally, so the presence of Turks in the palace did not signify a "Turkification" of the empire. There may have been more Turkish-born among the household troops (not least because many were the sons of janissaries) and in the Inner Court, but it was still the "Domains of the House of Osman" and not the "Turkish Empire" as Europeans insisted on calling it. 